\title{
ASSISTANCE FOR DENTISTS IN LITHUANIA
}

\author{
Vilija Berlin ${ }^{1}$, Alina Pūriené ${ }^{2}$, Greta Dulké $\dot{3}^{3}$ \\ ${ }^{\prime}$ Žalgiris Clinics of Vilnius University Hospital, Department of Orthodontics, \\ ${ }^{2}$ Žalgiris Clinics of Vilnius University Hospital, ${ }^{3}$ Vilnius University, Faculty of Medicine, Lithuania
}

Key words: dental assistant, dentist, ergonomics.

\begin{abstract}
Summary
The study objectives were to investigate the preference of Lithuanian dentists to work with or without an assistant and to identify the most significant predictors for the preference. As well, we aimed to explore the education of practicing dental assistants in Lithuania. The information was collected by a postal questionnaire survey which was carried out among all practicing general dental practitioners and dental specialists in Lithuania $(n=2971)$. The final response rate was $67.6 \%$ corresponding to 2,008 respondents. The results show that most dentists in Lithuania always or sometimes work without an assistant. Each third dentist of those who work with an assistant employ non-certified dental assistant. This may be done on purpose due to financial reasons. Dentists should be educated how efficient, ergonomic practice with a qualified dental assistant can be; inclusion of contemporary four-handed practice subject in applicants resume could improve employment of certified dental assistants in the long term.
\end{abstract}

\section{Introduction}

Modern dentistry is extremely interesting and attractive; it gives various possibilities for a dental practitioner to express her/his abilities and for patients to receive professional care. Despite that, dentists all over the world are subject to variety of occupational factors that affect their psychological and physical wellbeing. According to researchers all over the world, even young dentists face various psychological disorders such as burnout, stress, suicide and drug or alcohol addiction [1-6]. Majority of dentists (70$90 \%$ ) suffer from various physical occupational disorders neck, shoulders, lower back and wrist pain is the most common [7-12]. Lithuanian dentists face the same problem many of them complain with back pain $(91.0 \%)$, headache (88.7\%), hand problems $(83.1 \%)$ and chest pain (53.8\%), feel tired (82.6\%) and tense (80.5\%), suffer from anxiety $(78.8 \%)$ or nervousness $(89.2 \%)$, problems at work cause insomnia (74\%) and awakening at night (78.8\%); some dentists suffer from these symptoms constantly $[13,14]$. High volume workload is important stress trigger in clinical dentistry: $94.2 \%$ of Lithuania dentists claim experiencing negative health-related effects of long working hours and $41.7 \%$ of respondents experience these symptoms often or always [13]. Because of long working hours dentists have less time for themselves and tend to spend less time with their family. The research which investigated mental health and job satisfaction of Lithuanian dentists showed that about thirty percent of dentists are dissatisfied with personal time and time for their family they have [15].

Taking into an account the prevalence of physical, psychological occupational disorders and high volume workload in dentistry every effort should be made to make clinical practice more efficient and safe. Physical, psychological occupational factors and work efficiency can be addressed working with a qualified dental assistant. Dental assistant's help can contribute a lot to dentist's work. Four-handed dentistry minimizes damaging dentists' elbow and shoulder repetitive movements, avoids rotation of the trunk [16]. As a result, inflammation of muscles, joints and tendons which causes pain and limited movements is not encouraged. A dentist who shares work and responsibilities with a dental assistant can pay more attention to his patient, therefore expanded function personnel has a positive effect on quality of dental care [17]. Recent study among USA dentists showed that nearly one quarter of respondents felt that employing dental personnel who can perform auxiliary tasks would free up their time for more complex and interesting dental procedures [17]. Another research proved that practices that reported using allied dental personnel had more income, provided almost twice as many visits and had more auxiliary hours [18]. Various health professionals claim that share of responsibilities and daily contact among team members not only improve interrelations but also decrease stress and overload at work [19]. Therefore 
dentist working with the assistant is more productive, less tired and healthier. Teamwork and communication with colleagues is an important factor in order to have healthy working environment and successful career. It is more and more common in foreign countries, that dentists have more than one dental assistant helping them in their daily practice [20].

Considering high prevalence of physical and psychological occupational disorders and the negative effect of long working hours among Lithuanian dentists the aim of our study was to investigate the preference of Lithuanian dentists to work with or without an assistant, the most significant predictors for the preference and to explore the education of practicing dental assistants in Lithuania.

\section{Research methods}

The study was approved by the National Data Protection Inspectorate (No. 2R-3247). An ethics approval was not required due to the nature of the study. Contact information (e-mail, address, telephone number) of all licensed dentists in Lithuania was acquired from the License Registry of the Lithuanian Dental Chamber in October 2012. The retired and emigrated dentists were excluded from the sample. The overall study sample consisted of all licensed dentists and dental specialists in Lithuania $(n=2,971)$. All dentists were contacted up to three times. Firstly, depending on the available contact information (e-mail or address), questionnaires were sent either electronically or by post. Non-responders received copies of the same questionnaire again after six weeks. Those who did not respond after the second time were contacted again by phone six weeks later and the questionnaire was re-sent via their preferred mode. In total, 2,008 questionnaires were returned and the final response rate was $67.6 \%$. The data were collected from December 2012 to June 2013.

Reliability of the original study questionnaire was tested by asking 10 randomly chosen dentists and dental specialists to complete the questionnaire twice with a 2-month gap in between these recordings in order to avoid memory bias. The questionnaire items were structured on nominal, ordinal, and interval scales. The reliability of questions structured on nominal or ordinal scales was tested employing Cohen's kappa and interval scale responses were checked by intra-class correlation. Overall, the reliability was high for questionnaire items falling within the range 0.7 to 1.0 .

The SPSS statistical program version 21.0 was employed for all statistical analyses. Univariate analyses were used to describe the study sample regarding demographic characteristics and some study variables. The bivariate ana- lyses were done for the following purposes: non-response analyses $\left(\chi^{2}\right.$ test/Fisher test and independent samples $t$ test), comparisons between dentists working alone part/full time and dentists who work with an assistant full time as well as dentists who work with certified dental assistants/ hygienists and dentists who work with an assistant of other medical education or without medical education regarding their demographic and professional characteristics ( $\chi^{2}$ test), to explore the most significant predictors for the preference to work with or without an assistant, with medical professional or assistant without medical education (Odds Ratio). The threshold for significance for all tests was set at $P<0.05$. Due to some missing answers for individual questions of the questionnaire, the statistics for each question were based on a varying number of study subjects.

\section{Results}

The analyses showed no significant differences between responders and non-responders regarding the number of different dental specialists (oral surgeons, periodontologists, endodontists, prosthodontists, orthodontists and pediatric dentists; $(P=0.252)$. However, there were significantly fewer younger dentists $(P=0.001)$, males $(P<0.001)$, and dentists from big cities $(P<0.001)$ among the responders compared to the non-responders (results are not presented).

$21.9 \%$ of Lithuanian dentists constantly work alone, $37.4 \%$ work with an assistant sometimes and $40.7 \%$ work always with an assistant (Fig. 1). Statistical analysis showed that senior dentists, females, general dentists, dentist who work in suburban or rural areas, workers of public clinics $(p<0.001)$, owners of private practice or renters of dental chair $(\mathrm{p}=0.008)$, those who experience the shortage of patients ( $\mathrm{p}=0.03$ ) work without an assistant significantly more than younger dentists, males, dental specialists, dentists, who work in big cities and private clinics, associate dentists, those who do not feel the lack of patients (Table 1). Most significant predictors for working without an assistant were being a general dentist $(\mathrm{OR}=3.4)$, working in suburban or rural areas $(\mathrm{OR}=2.4)$ or experiencing the shortage of patients $(\mathrm{OR}=1.9)$.

The study showed that $66.4 \%$ of practicing dental assistants in Lithuania are certified and graduated from dental assistant study programs, $20.2 \%$ of dental assistants are professionals of other medical specialities (medical professionals), $8.6 \%$ are dental hygienists and $4.8 \%$ don't have medical education (Fig. 2). Statistical analysis show that younger dentists $(\mathrm{p}=0.016)$, general practitioners $(p=0.018)$, dentists of suburban/rural areas, owners of private practice, renters of dental chair $(p<0.001)$ and dentists who experience the shortage of patients $(p=0.012)$ work 


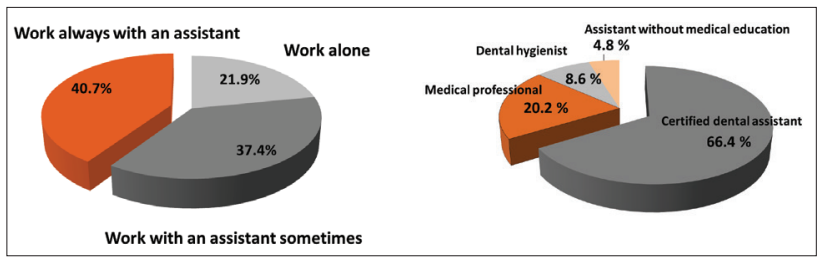

Fig. 1. Assistance for dentists in Lithuania.

Fig. 2. The education of dentists' assistants in Lithuania.

significantly more with medical professionals or assistants without medical education (Table 2). Most significant factors that predetermine the work with medical professionals or assistants without medical education are the lack of patients $(\mathrm{OR}=2.2)$, working in a private dental clinic $(\mathrm{OR}=2.2)$ and in suburban/rural area $(\mathrm{OR}=2.0)$.

\section{Discussion}

The present study findings indicate that majority of general dental practitioners and dental specialists in Lithuania do not have constant assistance during their clinical

Table 1. Comparison of demographic and professional characteristics between dentists who work with and without an assistant.

\begin{tabular}{|c|c|c|c|c|c|}
\hline \multirow[t]{2}{*}{$\begin{array}{l}\text { Demographic and } \\
\text { professional charac- } \\
\text { teristics }\end{array}$} & \multicolumn{2}{|c|}{$\begin{array}{l}\text { With medical } \\
\text { professional or } \\
\text { assistant without } \\
\text { medical edu- } \\
\text { cation (reference } \\
\text { group) }\end{array}$} & \multicolumn{2}{|c|}{$\begin{array}{l}\text { With certified } \\
\text { dental assistant } \\
\text { or hygienist }\end{array}$} & \multirow[t]{2}{*}{$\begin{array}{l}\text { P va- } \\
\text { lues, } \\
\text { OR }\end{array}$} \\
\hline & $\mathrm{N}$ & Mean \pm SD & $\mathrm{N}$ & Mean \pm SD & \\
\hline Age & 393 & $41.9 \pm 14.4$ & 1181 & $43.1 \pm 13.7$ & 0.016 \\
\hline Gender & $\mathrm{N}$ & $\%$ & $\mathrm{~N}$ & $\%$ & \\
\hline $\begin{array}{l}\text { Females (reference } \\
\text { group) }\end{array}$ & 333 & 25.2 & 986 & 74.8 & 0.562 \\
\hline Males & 60 & 23.5 & 195 & 76.5 & \\
\hline \multicolumn{6}{|l|}{ Dental professionals } \\
\hline $\begin{array}{l}\text { General dentists (re- } \\
\text { ference group) }\end{array}$ & 329 & 26.3 & 923 & 73.7 & \multirow[t]{2}{*}{$\begin{array}{c}0.018 \\
\text { OR-1.4 }\end{array}$} \\
\hline Specialists & 64 & 19.9 & 258 & 80.1 & \\
\hline \multicolumn{6}{|l|}{ Residence } \\
\hline $\begin{array}{l}\text { Suburban or rural } \\
\text { (reference group) }\end{array}$ & 147 & 34.7 & 277 & 65.3 & \multirow[t]{2}{*}{$\begin{array}{l}<0.001 \\
\text { OR-2.0 }\end{array}$} \\
\hline Big cities & 245 & 21.3 & 903 & 78.7 & \\
\hline \multicolumn{6}{|l|}{ Practice type } \\
\hline $\begin{array}{l}\text { Private (reference } \\
\text { group) }\end{array}$ & 223 & 27.5 & 588 & 72.5 & \multirow[t]{2}{*}{$\begin{array}{l}<0.001 \\
\text { OR-2.2 }\end{array}$} \\
\hline Public & 51 & 14.7 & 297 & 85.3 & \\
\hline \multicolumn{6}{|l|}{ Employment status* } \\
\hline $\begin{array}{l}\text { Owns private practice } \\
\text { or rents a dental chair } \\
\text { (reference group) }\end{array}$ & 143 & 30.8 & 321 & 69.2 & \multirow[t]{2}{*}{$\begin{array}{l}<0.001 \\
\text { OR-1.5 }\end{array}$} \\
\hline Associate dentist & 241 & 22.4 & 833 & 77.6 & \\
\hline \multicolumn{6}{|l|}{ Shortage of patients } \\
\hline Yes (reference group) & 16 & 38.1 & 26 & 61.9 & \multirow{2}{*}{$\begin{array}{c}0.012 \\
\text { OR-2.2 }\end{array}$} \\
\hline No & 236 & 21.7 & 851 & 78.3 & \\
\hline
\end{tabular}

practice. Present situation can be resulted by the lack of knowledge in ergonomics among Lithuanian dentists as the subject of dental ergonomics is being taught in Lithuanian universities only since 2010. Lithuanian Association of Dental Ergonomics was founded as well in 2010. It annually organizes postgraduate education courses where Lithuanian dentists are taught the principles of ergonomics. No ergonomic lectures were given before to the practicing dentists. Older dentists who practiced during the Soviet period before the regain of Lithuania's independence make

Table 2. Comparison of demographic and professional characteristics between dentists who work with certified dental assistant or hygienist and with medical professional or assistant without medical education.

\begin{tabular}{|c|c|c|c|c|c|}
\hline \multirow[t]{2}{*}{$\begin{array}{l}\text { Demographic } \\
\text { and profes- } \\
\text { sional charac- } \\
\text { teristics }\end{array}$} & \multicolumn{2}{|c|}{$\begin{array}{c}\text { With medical } \\
\text { professional } \\
\text { or assistant } \\
\text { without medical } \\
\text { education (refer- } \\
\text { ence group) }\end{array}$} & \multicolumn{2}{|c|}{$\begin{array}{l}\text { With certified } \\
\text { dental assistant } \\
\text { or hygienist }\end{array}$} & \multirow[t]{2}{*}{$\begin{array}{l}\text { P va- } \\
\text { lues, } \\
\text { OR }\end{array}$} \\
\hline & $\mathrm{N}$ & Mean \pm SD & $\mathrm{N}$ & Mean \pm SD & \\
\hline Age & 393 & $41.9 \pm 14.4$ & 1181 & $43.1 \pm 13.7$ & 0.016 \\
\hline Gender & $\mathrm{N}$ & $\%$ & $\mathrm{~N}$ & $\%$ & \\
\hline $\begin{array}{l}\text { Females (refer- } \\
\text { ence group) }\end{array}$ & 333 & 25.2 & 986 & 74.8 & 0.562 \\
\hline Males & 60 & 23.5 & 195 & 76.5 & \\
\hline \multicolumn{6}{|l|}{$\begin{array}{l}\text { Dental profes- } \\
\text { sionals }\end{array}$} \\
\hline $\begin{array}{l}\text { General den- } \\
\text { tists (reference } \\
\text { group) }\end{array}$ & 329 & 26.3 & 923 & 73.7 & \multirow[t]{2}{*}{$\begin{array}{l}0.018 \\
\text { OR-1.4 }\end{array}$} \\
\hline Specialists & 64 & 19.9 & 258 & 80.1 & \\
\hline \multicolumn{6}{|l|}{ Residence } \\
\hline $\begin{array}{l}\text { Suburban or } \\
\text { rural (reference } \\
\text { group) }\end{array}$ & 147 & 34.7 & 277 & 65.3 & \multirow[t]{2}{*}{$\begin{array}{l}<0.001 \\
\text { OR-2.0 }\end{array}$} \\
\hline Big cities & 245 & 21.3 & 903 & 78.7 & \\
\hline \multicolumn{6}{|l|}{ Practice type } \\
\hline $\begin{array}{l}\text { Private (refer- } \\
\text { ence group) }\end{array}$ & 223 & 27.5 & 588 & 72.5 & \multirow[t]{2}{*}{$\begin{array}{l}<0.001 \\
\text { OR-2.2 }\end{array}$} \\
\hline Public & 51 & 14.7 & 297 & 85.3 & \\
\hline \multicolumn{6}{|c|}{ Employment status* } \\
\hline $\begin{array}{l}\text { Owns private } \\
\text { practice or } \\
\text { rents a dental } \\
\text { chair (reference } \\
\text { group) }\end{array}$ & 143 & 30.8 & 321 & 69.2 & \multirow[t]{2}{*}{$\begin{array}{l}<0.001 \\
\text { OR-1.5 }\end{array}$} \\
\hline $\begin{array}{l}\text { Associate den- } \\
\text { tist }\end{array}$ & 241 & 22.4 & 833 & 77.6 & \\
\hline \multicolumn{6}{|c|}{ Shortage of patients } \\
\hline $\begin{array}{l}\text { Yes (reference } \\
\text { group) }\end{array}$ & 16 & 38.1 & 26 & 61.9 & \multirow[t]{2}{*}{$\begin{array}{l}0.012 \\
\text { OR-2.2 }\end{array}$} \\
\hline No & 236 & 21.7 & 851 & 78.3 & \\
\hline
\end{tabular}


significant part of the present dental workforce which is hardly receptive to innovations. It is known, that it is not so easy to apply ergonomic knowledge in clinical practice for dentists who are not used to work in ergonomic way. Ergonomics is a discipline which requires a profound and systematic approach, regular practical training and control [21-23]. Therefore the promotion of ergonomics in dentistry should be highly encouraged by universities, Lithuanian Association of Dental Ergonomics and all the organizers of postgraduate courses in Lithuania.

Despite all the advantages a dentist has when working with the dental assistant, hiring of ancillary personnel in dental offices has one disadvantage - it is the matter of financial burden [24]. Our study show, that according to the factors predicting working without an assistant (shortage of patients, work in a suburban/ rural area, being general practitioner) it can be supposed, that not hiring an assistant may be done on purpose due to financial reasons. These financial reasons could be more important than practitioners' health due to lack of knowledge about the acute problem of the prevalence of physical and psychological disorders in dentistry. Dentists who care about their health, has management and ergonomic knowledge know that it is obligatory to use the help of dental assistant to be healthy and have an efficient practice $[16,18,19]$.

Dentists should focus on performing tasks that only they can perform, other tasks in the dental surgery should be delegated to ancillary personnel. Certified dental assistants are trained to perform various complex tasks, develop an effective four-handed dentistry practice in the dental surgery. Competent dental assistant increases productivity, reduces stress and strain on practicing dentist [17-19]. The results of the study show, that each third dentist of those who work with an assistant employ non-certified dental assistant (i.e. medical professional, dental hygienist or assistant without medical education). As younger dentists, general practitioners, dentists of suburban/rural areas, owners of private practice, renters of dental chair and dentists who experience the shortage of patients chose to work with a non-certified dental assistant, this can be done also due to financial reasons.

According to the data of Lithuanian Dental Chamber, there is an absolute shortage of certified dental assistants with only 0.5 dental assistant per dentist in Lithuania [25]. One reason for this ratio is high emigration of the professionals. The study in Lithuania showed that dental assistant graduates scored the highest rate $(35.5 \%)$ among all dental care graduates intending to seek employment abroad. General dentists reported a rate of $26.9 \%, 19.4 \%$ of dental hygienists, $15.1 \%$ of technicians and $3.2 \%$ of dental speci- alists were planning to leave the country [26]. The salary of dental assistant in Lithuanian capital health institutions is low and makes about 600-800 Eur before taxes [28-30]. The possibility to earn money for personal housing, higher salary, possibility for new acquaintances, better living and working conditions were identified as the most important by the dental assistants seeking to work abroad [26]. An absolute shortage of certified dental assistants in Lithuania was addressed of the responsible institutions introducing a specialty of a dentist helper in 2012 [27]. This measure was the quick and effective way to address the shortage of the workforce in dental healthcare system. Nevertheless, these specialists learn only for 3 months and their knowledge and practical skills are limited. Certified dental assistants are trained for 3 years, they can be much more effective in the dental surgery. According to the results of our study, Lithuanian dentists should be taught that it is more effective to work with a qualified dental assistant rather than a specialist with low qualification and how to utilize the dental assistant's qualification fully. The same recommendations for foreign dental schools can be found in the literature - students should learn how to utilize their staff members more effectively [17]. Inclusion of contemporary four-handed practice subject in the curriculum could improve employment and increase the value of the profession of certified dental assistants in the long term.

\section{Conclusions}

Most dentists in Lithuania always or sometimes work without an assistant. Each third dentist of those who work with an assistant employ non-certified dental assistant. This may be done on purpose due to financial reasons. They should be educated how efficient, ergonomic practice with a qualified dental assistant can be; inclusion of contemporary four-handed practice subject in the curriculum could improve employment of certified dental assistants in the long term. The growing discrepancy of the supply and demand of certified dental assistants should be addressed.

\section{References}

1. Brondani M, Ramanula D, Pattanaporn K. Tackling stress management, addiction and suicide prevention in a predoctoral dental curriculum. Journal of Dental Education 2014; 78(9):1286-1293.

2. Jugale P, Mallaiah P, Krishnamurthy A, Sangha R. Burnout and work engagement among dental practitioners in Bangalore city: a cross-sectional study. J Clin Diagn Res 2016; 10(2):63-67. https://doi.org/10.7860/jcdr/2016/16009.7312

3. Singh P, Aulak D, Mangat S, Aulak M. Systematic review: factors contributing to burnout in dentistry. Occup Med (Lond) 
2016; 66(1):27-31.

https://doi.org/10.1093/occmed/kqv119

4. Mache S, Vitzthum K, Groneberg D. Prevention of study-related stress symptoms: health promoting behaviour among dental students. Wien Med Wochenschr 2015; 165(5):100-106.

https://doi.org/10.1007/s10354-014-0341-6

5. Vilà Falgueras M, Cruzate Mu-oz C, Orfila Pernas F, Creixell Sureda J, González López MP, Davins Miralles J. Burnout and teamwork in primary care teams. Aten Primaria 2015; 47(1):25-31.

https://doi.org/10.1016/j.aprim.2014.01.008

6. Casta-eda Aguilera E, García de Alba García JE. Analysis of possible sociodemographic and occupational risk factors and the prevalence of professional exhaustion syndrome (Burnout) in Mexican dentists. Rev Colomb Psichiatr 2013; 42(2):182-190.

7. Rafie F, Zamani Jam A, Shahravan A, Raoof M, Eskandarizadeh A. Prevalence of upper extremity musculoskeletal disorders in dentists: symptoms and risk factors. J Environ Public Health 2015; 2015:517346.

https://doi.org/10.1155/2015/517346

8. Wang S Y, Liu L C, Lu M C, Koo M. Comparisons of musculoskeletal disorders among ten different medical professions in Taiwan: a nationwide, population-based study. Plos One 2015; 10(4): e0123750.

https://doi.org/10.1371/journal.pone. 0123750

9. Yasobant S, Rajkumar P. Work-related musculoskeletal disorders among healthcare professionals: A cross-sectional assessment of risk factors in a tertiary hospital, India. IJOEM 2014; 18(2): 75-81.

https://doi.org/10.4103/0019-5278.146896

10. Feng B, Liang Q, Wang Y, Andersen L L, Szeto G. Prevalence of work-related musculoskeletal symptoms of the neck and upper extremity among dentists in China. BMJ Open 2014; 4(12):e006451.

https://doi.org/10.1136/bmjopen-2014-006451

11. Oliveira Dantas F F, de Lima K C. The relationship between physical load and musculoskeletal complaints among Brazilian dentists. Appl Ergon 2015; 47:93-8.

https://doi.org/10.1016/j.apergo.2014.09.003

12. Muralidharan D, Fareed N, Shanthi M. Musculoskeletal disorders among dental practitioners: does it affect practice? Epidemiology Research International 2013; 2013: e716897.

13. Puriene A, Aleksejuniene J, Petrauskiene J, Balciuniene I, Janulyte V. Occupational hazards of dental profession to psychological wellbeing. Stomatologija 2007; 9(3):72-8.

14. Puriene A, Aleksejuniene J, Petrauskiene J, Balciuniene I, Janulyte V. Self-reported occupational health issues among Lithuanian dentists. Industrial Health 2008; 46:369-374. https://doi.org/10.2486/indhealth.46.369

15. Puriene A, Petrauskiene J, Janulyte V, Balciuniene I. Factors related to job satisfaction among Lithuanian dentists. Stoma- tologija 2007; 9(4):109-13.

16. Sarkar P, Shigli A. Ergonomics in general dental practice. People's Journal of Scientific Research 2012; 5(1): 56-60.

17. Blue C, Funkhouser E, Riggs S, Rindal B, Worley D, Pihlstrom D, Benjamin P, Gilbert G. Utilization of non-dentist providers and attitudes toward new provider models: findings from the national dental practice-based research network. J Public Health Dent 2013; 73(3): 237-244.

https://doi.org/10.1111/jphd.12020

18. Beazoglou T, Chen L, Lazar V, Brown J, Ray S, Heffley D, Berg R, Bailit H. Expanded function allied dental personnel and dental practice productivity and efficiency. Journal of Dental Education 2012; 76: 81054-1060.

19. Da Costa Saar S, Trevizan M. Professional roles of a health team: a view of its components. Rev. Latino-Am. Enfermagem 2007; 15(1): 106-112. https://doi.org/10.1590/S0104-11692007000100016

20. Indian Health Service. Dental clinic efficiency and effectiveness manual. Oral Health Program Guide 2007.

21. Garcia PP, Gottardello AC, Wajngarten D, Presoto CD, Campos JA. Ergonomics in dentistry: experiences of the practice by dental students. Eur J Dent Educ 2016.

https://doi.org/10.1111/eje.12197

22. Garbin AJ, Garbin CA, Diniz DG, Yarid SD. Dental students' knowledge of ergonomic postural requirements and their application during clinical care. Eur J Dent Educ 2011;15(1):31-35. https://doi.org/10.1111/j.1600-0579.2010.00629.x

23. Movahhed T, Dehghani M, Arghami S, Arghami A. Do dental students have a neutral working posture? J Back Musculoskelet Rehabil 2016: 1-6.

24. Leontief W, Duchin F. The future impact of automation on workers. New York Oxford University Press. 1986.

25. Lithuanian Dental Chamber. [Lithuanian Dental Chamber 2012-2016]. 2016

26. Janulyte V, Puriene A, Petrauskiene J, Peciuliene V, Benzian H. International migration of Lithuanian oral health professionals: a survey of graduates. Int Dent J 2011; 61(4):224-230. https://doi.org/10.1111/j.1875-595X.2011.00062.x

27. Lithuanian Dental Chamber. Internet access: http://odontologurumai.lt/lt/apie-rumus/naujienos/236-parengta-pirmojiodontologo-pagalbinink\% $\% 5 \% \mathrm{~B} 3$-grup $\% \mathrm{C} 4 \% 97$ [viewed on 15th October 2016].

28. Vilnius University Hospital Zalgiris Clinic. Internet access: http://www.zalgirioklinika.lt/upl/File/darbo.uzmokestis/ InformacijaapieDU2015.pdf [viewed on 15th October 2016].

29. Centre Clinic. Internet access: http://www.pylimas.lt/assets/ Uploads/Vid.-darbo-umokestis/Vidutinis-DU-2016m-II-ketv. pdf [viewed on 15th October 2016].

30. Vilnius District Centre Clinic. Internet access: http:// www.vrcp.lt/go.php/Informacija $\% 20$ apie $\% 20$ darbo $\% 20$ $\mathrm{u} \% \mathrm{C} 5 \% \mathrm{BEmokest} \% \mathrm{C} 4 \% \mathrm{AF} 80$ [viewed on 15 th October]. 
ASISTAVIMAS GYDYTOJAMS ODONTOLOGAMS

\section{LIETUVOJE}

\section{Berlin, A. Pūrienė, Greta Dulkè}

Raktažodžiai: odontologo padejjejjas, odontologas, ergonomika. Santrauka

Tyrimo tikslai: išsiaiškinti, ar Lietuvos odontologai dirba su odontologo padèjèju ar be jo pagalbos bei nustatyti reikšmingiausius veiksnius, nulemiančius pasirinkimą dirbti be asistento pagalbos. Taip pat šiuo tyrimu buvo siekiama išsiaiškinti Lietuvoje praktikuojančių odontologų padejjèjų ígytą išsilavinimą.

Medžiagos ir metodai: informacija gauta apklausos būdu išsiuntus anketą paštu visiems Lietuvos bendrosios praktikos odontologams bei odontologams specialistams $(n=2971)$. Galutinė atsakymų vertė siekè 67,6\% (2.008 respondentų).

Rezultatai: 21,9\% Lietuvos odontologų dirba vieni visada, $37,4 \%$ dirba su padejeju, kartais ir 40,7\% dirba su asistentu nuolat. Statistinè analizė parodè, kad vyresnio amžiaus, moteriškos lyties, mažame mieste ar valstybinèse įstaigose dirbantys, turintys bendrosios praktikos gydytojo odontologo licenciją $(\mathrm{p}<0,001)$, privačios praktikos savininkai ar nuomuojantys odontologinę kėdę $(\mathrm{p}=0.008)$, nusiskundžiantys pacientų trūkumu $(\mathrm{p}=0.03)$ dirba be odontologo padejjejo pagalbos reikšmingai dažniau. Reikšmingiausi darbą be asistento pagalbos nulemiantys veiksniai yra bendrosios praktikos gydytojo odontologo darbas $(\mathrm{OR}=3.4)$, darbas mažame mieste $(\mathrm{OR}=2.4)$ bei pacientų trūkumas $(\mathrm{OR}=1.9)$. Tyrimas parodè, kad 66,4\% praktikuojančių odontologų padejjejų turi darbo licenciją ir yra pabaigę odontologų asistentų studijas, 20,2\% padejjejų yra pabaigę kitas medicinos srities studijas, $8,6 \%$ yra burnos higienistai ir 4,8\% neturi medicininio išsilavinimo. Statistinè analizė parodé, kad jaunesnio amžiaus $(\mathrm{p}=0.016)$ bendrosios praktikos gydytojai $(\mathrm{p}=0.018)$, dirbantys mažuose miestuose, privačios praktikos savininkai, nuomuojantys odontologinę kèdę $(p<0.001)$ bei turintys pacientų trūkumą $(\mathrm{p}=0.012)$ dirba statistiškai reikšmingai dažniau su asistentu, neturinčiu medicininio išsilavinimo ar baigusiu kitas medicinos srities studijas. Reikšmingiausi veiksniai, nulemiantys darbą su padejejju, neturinčiu medicininio išsilavinimo ar baigusiu kitas medicinos srities studijas, yra pacientų trūkumas $(\mathrm{OR}=2.2)$, darbas privačioje odontologijos klinikoje $(\mathrm{OR}=2.2)$ ar mažame mieste $(\mathrm{OR}=2.0)$.

Išvados. Didžioji dauguma Lietuvos odontologų dirba visada ar kartais be padejejjo pagalbos. Kas trečias odontologas, dirbantis su asistentu, dirba su nesertifikuotu odontologo padejejju. Pasirinkimas dirbti be odontologo padejejjo ar su nesertifikuotu asistentu gali būti susijęs su finansine našta gydytojui. Odontologai turi būti mokomi, kad darbas su padejèju yra efektyvus bei ergonomiškas. „Keturių rankų“ ergonomiško darbo patirties turejjimas bei šios patirties nurodymas darbuotojo CV gali paskatinti kvalifikuotų odontologo padejejęu įdarbinimą ateityje.

Adresas susirašinèti: greta.dulke@yahoo.com

Gauta 2016-11-23 